\title{
Changes in the serum protein electrophoretic pattern in lambs during the first month of life
}

\author{
Oskar Nagy, Csilla Tóthová, Veronika Nagyová, Gabriel Kováč, Ján Pošivák \\ University of Veterinary Medicine and Pharmacy, Clinic for Ruminants, Košice, Slovak Republic
}

Received October 16, 2013

Accepted May 28, 2014

\begin{abstract}
Studies of the changes in serum protein pattern in the neonatal period in animals are still limited. Therefore, the objective of this study was to evaluate the changes in the concentrations of serum protein fractions in 7 clinically healthy merino lambs ( 4 males, 3 females) during their first month of life. The first blood sampling was performed before the colostrum intake and then at $1,2,7,14$ and 30 days of age. Blood serum was analysed for total serum protein concentrations and for the relative and absolute values of serum protein fractions - albumin, alpha $-\left(\alpha_{1}\right)$, alpha $-\left(\alpha_{2}\right)$, beta$(\beta)$, and gamma- $(\gamma)$ globulins. The results showed a significant effect of age on the serum total protein concentrations and for all the protein fractions. The concentrations of total proteins and $\gamma$-globulins increased significantly 1 day after the colostrum intake $(P<0.001)$; then decreased gradually till the end of the $1 \mathrm{st}$ month. An opposite trend was observed in the concentrations of albumin. A significant decrease of values was found 1 day after the intake of colostrum $(P<0.001)$ with a subsequent progressive increase of values till the end of the evaluated period. The relative concentrations of $\alpha_{1}$-globulins significantly decreased during the first month of life $(P<0.001)$. On the other hand, the relative values of $\alpha_{2}$ - and $\beta$-globulins increased significantly from birth till the end of the monitored period $(P<0.001)$. Our results suggest that the serum protein electrophoretic pattern in growing lambs is significantly influenced by the age of the evaluated animal, and this should be taken into consideration when interpreting the serum protein profile. Our findings extend existing knowledge about significant changes in the protein profile associated with the physiological adaptation process in the neonatal period in young animals.
\end{abstract}

Small ruminants, neonatal period, colostrum, nutrition, protein fractions

The total protein content of serum is made up of a large number of individual proteins, and diagnostic information can be obtained by the evaluation of changes in the total serum protein concentrations or in different protein fractions (Eckersall 2008). Because the total proteins represent the sum of albumin and globulins, it is more important to know which protein fraction is altered. Valuable diagnostic information can be obtained using electrophoresis to fractionate serum proteins and determine the concentrations of major protein fractions (Tietz et al. 1994). Changes in serum proteins can be indicative of health problems and may provide important diagnostic information to clinicians in confirming the diagnosis of various abnormalities and diseases.

Serum protein electrophoresis is a very important laboratory technique for the diagnosis of a wide variety of disorders and diseases, including paraproteinaemias, immune deficiency, various protein abnormalities, and for the determination of the underlying nature of hyperproteinaemia or hyperglobulinaemia (Keren et al. 1999). Many diseases are associated with subtle or more marked alterations in the serum protein pattern. Variations in the serum protein profile and in the concentrations of protein fractions may occur not only under pathological, but also under physiological conditions (Weaver et al. 2000; Janku et al. 2011). Several studies have confirmed that in young animals, changes in nutrition, body growth, and development, are accompanied by dynamic changes in many indices of haematological, mineral, enzymatic, energy, and other profiles, including serum protein profile (Egli and Blum 1998; Mohri et al. 2007; Piccione et al. 2009). Most of these

Address for correspondence:

Oskar Nagy, Assoc. Prof., DVM, PhD.

University of Veterinary Medicine and Pharmacy, Clinic for Ruminants

Komenského 73,041 81 Košice, Slovak Republic

\author{
Phone: +421915986695 \\ Fax: +421556711674 \\ E-mail: onagy@uvlf.sk \\ http://actavet.vfu.cz/
}


studies were performed in young calves. Some authors studied the acid-base balance in lambs and goat kids during the first week of life in order to provide useful information for the diagnosis and treatment of some neonatal diseases (Piccione et al. 2006). However, studies dealing with changes in the serum protein pattern and in concentrations of protein fractions in lambs during the period after birth are still limited. Seeing that this is the most vulnerable period in the life of any animal, the objective of this study was to evaluate the influence of age, growth and development on the serum protein profile and changes in the concentrations of serum protein fractions in clinically healthy lambs during the first month of life.

\section{Materials and Methods}

Seven merino lambs born at the Clinic for Ruminants were used in this study. The lambs were born with a mean birth weight of $3.4 \pm 0.2 \mathrm{~kg}$ and reached a mean body weight of $9.3 \pm 0.2 \mathrm{~kg}$ at the end of the $1^{\text {st }}$ month of life. Within 30 min after birth, a "zero" blood sample was collected; subsequently, lambs were fed colostrum. During the first days of life the lambs were fed colostrum, and later mature milk. During the study, the lambs were allowed to suck freely on their dams and were housed together with their mothers. The animals had free access to water, hay and concentrates. The lambs were observed daily. All animals were clinically healthy and in a good general health condition without any obvious clinical signs of diseases during the time of the study. The first blood sampling in the lambs was performed before the colostrum intake (day 0 ) and then at 1,2, 7, 14, and 30 days (d) of age. Blood was collected by direct puncture of $\mathrm{v}$. jugularis into tubes with serum cloth activator (Meus, Piove di Sacco, Italy). Blood samples were allowed to clot at room temperature, and then centrifuged at $3000 \times g$ for $30 \mathrm{~min}$ to separate serum. The harvested blood serum was dispensed into plastic tubes, and stored at $-20^{\circ} \mathrm{C}$ until analysed.

Blood serum was analysed for the concentrations of total proteins (TP, g/l), and serum protein fractions. Total protein concentrations were assessed on an automated biochemical analyser Alizé (Lisabio, France) by the biuret method using commercial diagnostic kits (Randox, United Kingdom). Serum protein fractions were separated by zone electrophoresis on a buffered agarose gel at $\mathrm{pH} 8.8$ on an automated electrophoresis system Hydrasys (Sebia Corporate, France) using commercial diagnostic kits Hydragel 7 Proteine (Sebia Corporate, France) according to the procedure described by the manufacturer. The electrophoretic gels were scanned, and the serum protein fractions were visualised and displayed on densitometry system Epson Perfection V700 (Epson America Inc., California, USA) by light transmission and automatic convertion into an optical density curve presentation. Protein fractions were identified and quantified by computer software Phoresis version 5.50 (Sebia Corporate, France), and where necessary, corrected by visual inspection of the electrophoretogram.

Serum proteins were separated into the following fractions in the order of the fastest to the slowest mobilities: albumin (Alb), alpha ${ }_{1}\left(\alpha_{1}\right)$-, alpha ${ }_{2}\left(\alpha_{2}\right)$-, beta ( $\beta$ ) -, and gamma $(\gamma)$-globulins. Relative concentrations (\%) of the protein fractions were determined as the percentage of optical absorbance, and absolute concentrations $(\mathrm{g} / \mathrm{l})$ were calculated from the total serum protein concentrations. Albumin : globulin ratios $(A / G)$ were computed from the electrophoretic scan.

Arithmetic means (x) and standard deviations (SD) expressed as relative and absolute concentrations for each evaluated variable and sample collection were calculated using descriptive statistical procedures. The effect of age on changes of the evaluated indices during the whole monitored period was examined by non-parametric Friedman's rank sum test. Significance of differences in values between the sample collections were evaluated by Dunn's Multiple Comparisons Test. All statistical analyses were carried out using the GraphPad Prism V5.02 programme (GraphPad Software Inc., California, USA).

\section{Results}

Serum protein electrophoresis identified five distinct bands in the lambs, comprising albumin, two $\alpha$-globulin $\left(\alpha_{1}\right.$ and $\left.\alpha_{2}\right), \beta$-globulin and $\gamma$-globulin fractions (Table 1). Albumin was the most prominent protein fraction, constituting on average $69.1 \%$ of total serum proteins at birth. Its relative concentrations decreased significantly 1 day after colostrum intake $(P<0.001)$. From the $2^{\text {nd }}$ day till the end of the first month of life, a gradual increase of the values was observed. These changes during the evaluated period were significant $(P<0.001)$. Sampling time had a significant effect on the relative concentrations of $\alpha_{1}{ }^{-}$ globulins $(P<0.001)$. Their values gradually decreased significantly from birth up to day 30 of life. An opposite trend of significantly increasing values was observed in the relative concentrations of $\alpha_{2}$-globulins $(P<0.001)$. An increase of $\alpha_{2}$-globulins was found from 


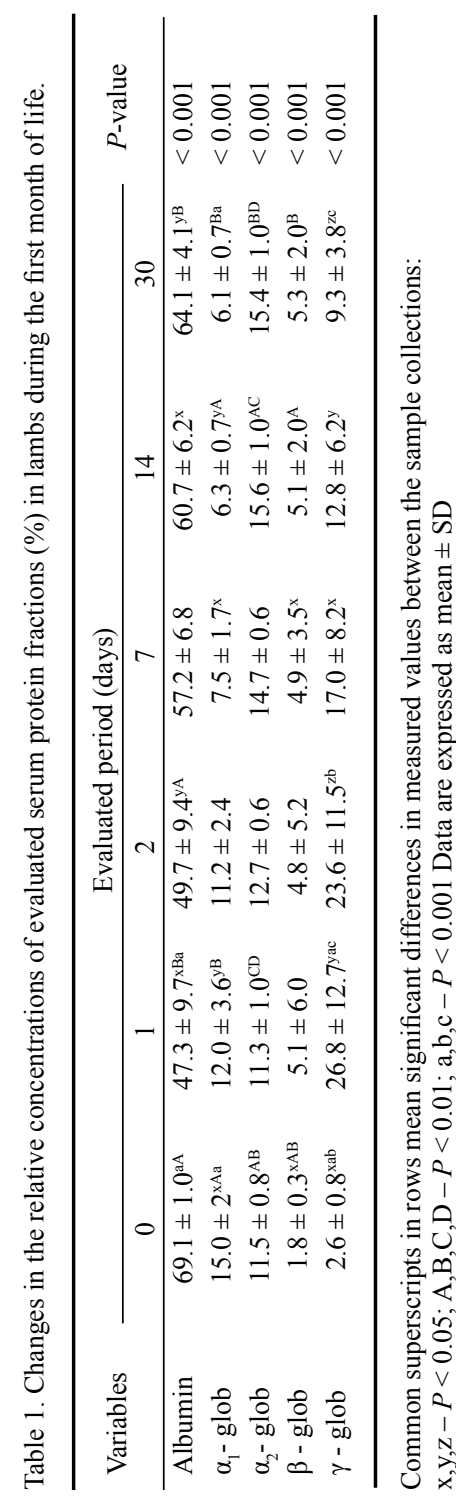

day 2 after birth with significantly the highest values in lambs at the age of 14 and 30 days compared to values measured at birth $(P<0.001)$. Significant age-related changes were also found for $\beta$-globulins $(P<0.001)$. The lowest mean relative concentration was found at birth. The values recorded from the $1^{\text {st }}$ day of life were markedly higher with significantly the highest relative concentration on day 30. A significant effect of age was found also in the relative concentrations of $\gamma$-globulins $(P<0.001)$. At birth, the mean relative concentration of this protein fraction was $2.6 \%$, increasing significantly 1 day after colostrum intake $(P<0.001)$. From the $2^{\text {nd }}$ day of life, a gradual decrease of their concentrations was found till the end of the first month of life.

Concentrations of total proteins in relation to the age of the lambs showed significant changes during the first month of life (Table 2, $P<0.001$ ). The lowest concentration of TP was observed at birth with a subsequent significant increase of values $1 \mathrm{~d}$ after colostrum intake $(P<0.001)$. In the following days the values were lower and relatively stable until the end of the evaluated period. Significant changes during the evaluated time were found in the concentrations of albumin $(P<0.001)$. During the first 2 days of life, the values were relatively stable. On the $7^{\text {th }}$ day of life, a marked increase of albumin concentrations was observed with a further significant increase of values till the end of the first month. The age of lambs had a significant effect on the absolute concentrations of $\alpha_{1}$-globulins $(P<0.001)$. The highest mean values were found on the $1^{\text {st }}$ day of life. From the $2^{\text {nd }}$ day of life, a gradual decrease of their values was observed till the end of the evaluated period. Significant changes were found also in the absolute concentrations of $\alpha_{2}$-globulins $(P<0.001)$. The lowest mean value was recorded at birth. A more marked increase of their values was recorded from day 1 after birth. Concentrations of $\beta$-globulins increased significantly with advanced age $(P<0.001)$. Age had a significant effect also on the concentrations of $\gamma$-globulins $(P<0.001)$. Their lowest mean value was found at birth. One day after colostrum intake, their concentrations increased significantly $(P<0.001)$, with a subsequent significant decrease till the end of the first month of life. The $\mathrm{A} / \mathrm{G}$ ratios also showed significant changes during the evaluated period $(P<0.001)$. The highest mean value was recorded at birth, and the lowest on the first day after birth.

\section{Discussion}

The period after birth represents the most critical time in lamb rearing, during which the development of physiological functions necessary to adapt to life outside the uterus take place. Newborns are in a metabolically unstable condition accompanied by intense 


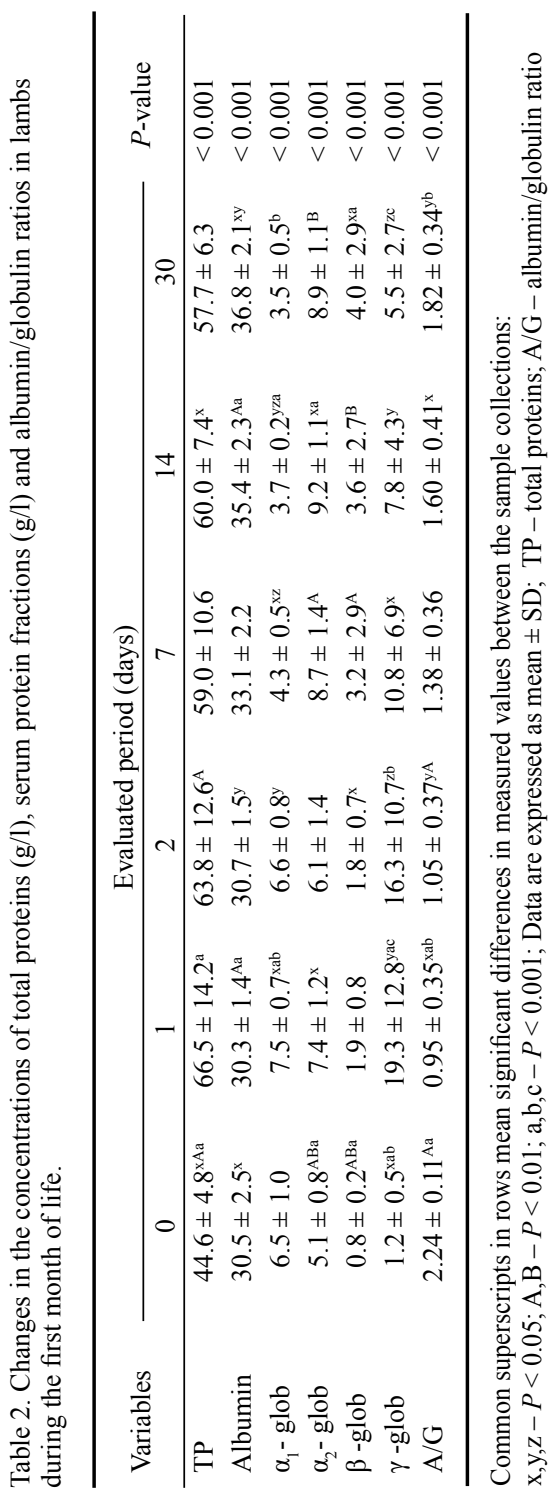

morphological, functional, and biochemical changes (Dwyer 2008). It is very important to know the physiological serum protein electrophoretic pattern and the values of different protein fractions in animals, in order to be able to distinguish them from pathological conditions. In this respect, it is also important to know the possible variations in the serum protein profile during the neonatal period.

Our results obtained in lambs during the first month of life showed a significant effect of age on the concentrations of total serum proteins and the values of all protein fractions. The low concentration of total serum proteins observed at birth was followed by its marked increase after colostrum intake. Hammon et al. (2002) reported that at birth, serum protein concentrations of most animals are quite low due to minimal quantities of immunoglobulins. The increase in their values during the first $24 \mathrm{~h}$ of life reflects the intestinal absorption of proteins (particularly immunoglobulins) from colostrum due to enhanced intestinal permeability. Piccione et al. (2013) found also in lambs the highest total protein concentrations on the first day of life with a decrease on day 4, and then a progressive increase until the end of the first month of life. Our results showed relatively stable values of total proteins from day 7 of life until the end of the first month. This change was probably due to the degradation of colostral immunoglobulins (Mohri et al. 2007). In concentrations of albumin, a progressive increase of their values during the development from birth was seen in calves (Ježek et al. 2006). According to Davis et al. (1998), the increase of albumin with age is a physiological phenomenon, and higher concentrations of albumin in young and growing animals help to maintain metabolic balance. Our results showed relatively stable absolute concentrations of albumin in lambs during the first 2 days of life with a progressive increase from the $7^{\text {th }}$ day till the end of the first month of life. Piccione et al. (2013) found in lambs the highest albumin concentrations on the first day of life. Its concentrations decreased during the first 2 weeks of life and started to increase with the beginning of the $3^{\text {rd }}$ week until the end of the first month of life. A similar trend was observed by Piccione et al. (2011) in goat kids. For the relative concentrations of albumin, the highest peak was observed after birth, followed by a marked decrease 1 day after colostrum intake and an increase from day 2 after birth. According to Tho mas (2000), this pattern is caused by changing globulin concentrations during development 
(higher relative concentrations of albumin and lower relative concentrations of $\gamma$-globulins in very young animals).

Significant age related variations were found for relative concentrations of $\alpha_{1}$ globulins, with the highest values at birth. Their values decreased gradually till the end of the first month of life. Similar findings were reported by Szewczuk et al. (2011) in calves, who found higher concentrations of $\alpha$-globulins on day 5 compared to values measured on day 30 of life. In contrast to our results, Piccione et al. (2013) recorded a progressive decrease of $\alpha_{1}$-globulins in lambs during the first 2 weeks of life. Many of the acute phase proteins migrate in the $\alpha$-globulin region (haptoglobin, ceruloplasmin, $\alpha_{1}$-acid glycoprotein, $\alpha_{1}$-antitrypsin), and environmental conditions represent an important trigger for a shift in acute phase proteins. Some increases in the concentrations of $\alpha$-globulins may be present in conditions unrelated to inflammatory diseases (Lomborg et al. 2008). Therefore, higher relative concentrations of $\alpha$-globulins in lambs shortly after birth are not necessarily a sign of activation of inflammatory processes, or a sign of disease. The higher values of $\alpha$-globulins in lambs in a short period after birth obtained in our study may be associated with the normal process of growth, and may be related to the exposure of animals to changing environmental conditions and nutritional factors. Kaneko et al. (2008) reported that blood sera of newborn and young animals contain large amounts of $\alpha$-globulins due to higher concentrations of some of the proteins from this fraction, which are to protect young animals from immune system attacks. According to Bishop et al. (2010), $\alpha_{1}{ }^{-}$ fetoprotein represents one of these proteins, which is synthesized in the developing fetus and then by the parenchymal cells of the liver, and its serum concentrations decrease progressively after birth. Therefore, higher relative concentrations of $\alpha_{1}$ globulins in lambs in the first days after birth recorded in our study may reflect the accumulation of $\alpha_{1}$-fetoprotein in the blood serum of young animals. The $\beta$-globulins showed a progressive increase of values from the $1^{\text {st }}$ day of life till the end of the $1^{\text {st }}$ month. Similar data were reported in goat kids and in lambs by Piccione et al. (2011, 2013). These findings may be related to the increase of some proteins, especially complement proteins, from this fraction which like the acute phase proteins are involved in the environmental stress response (Bernabucci et al. 2009).

Proteins that compose the $\gamma$-globulin fraction are principally the immunoglobulins. Our study indicated a significant effect of age also on this fraction with a substantial increase 1 day after the colostrum intake. These changes after birth reflect the absorption of immunoglobulins with a colostral uptake during the first $24 \mathrm{~h}$. Like in calves, precolostral serum in lambs normally contains no $\gamma$-globulins but within a few hours after the ingestion of colostrum, $\gamma$-globulins appear in serum, and the absorption continues for up to $36 \mathrm{~h}$ after birth, after which gut permeability ceases (Weaver et al. 2000). The immunoglobulins absorbed from colostrum provide humoral immunity for the newborn animals until they can produce immunoglobulins on their own in sufficient amounts to provide protection against infectious agents (Meyer and Harvey 2004). Piccione et al. (2011) recorded a small increase of $\gamma$-globulins in goat kids from day 14 till the end of the $1^{\text {st }}$ month of life. On the other hand, our results showed a progressive decrease of their concentrations in lambs from day 2 after birth till the end of the $1^{\text {st }}$ month of age, which may probably be attributed to degradation of colostrum-derived immunoglobulins and gradual initiation of the production of own immunoglobulins by the maturing immune system. Our results suggest a marked shift in the concentrations of albumin and globulins in lambs during the first month of life, presumably caused by changing globulin patterns during growth and development. These changes reflect the variations found in the $\mathrm{A} / \mathrm{G}$ ratios. According to Alberghina et al. (2010), the $\mathrm{A} / \mathrm{G}$ ratio must be interpreted cautiously, paying attention to which part of the ratio has changed because it allows systematic classification and identification of dysproteinaemias. 
In conclusion, the results of our study showed that the serum protein electrophoretic patterns in lambs are significantly influenced by age, growth and development. Significant changes were found in albumin and the whole globulin fraction, reflecting the changes in nutrition and homeostasis during growth and development. Thus, our results suggest that the changes in the serum protein electrophoretic profile may indicate not only various diseases; but modifications of the proteinogram in lambs during the first 30 days of life may be associated with physiological adaptation processes. This shift also suggests that the age of evaluated animals should be taken into consideration when interpreting serum protein electrophoretic profiles.

\section{Acknowledgements}

This work was supported by the Slovak Research and Development Agency under contract No. APVV-0475-10 and by VEGA Scientific Grants No. 1/0447/14 and 1/0812/12.

\section{References}

Alberghina D, Casella S, Vazzana I, Ferrantelli V, Giannetto C, Piccione G 2010: Analysis of serum proteins in clinically healthy goats (Capra hircus) using agarose gel electrophoresis. Vet Clin Pathol 39: 317-321

Bernabucci U, Lacetera N, Danieli PP, Bani P, Nardone A, Ronchi B 2009: Influence of different periods of exposure to hot environment on rumen function and diet digestibility in sheep. Int J Biometeorol 53: 387-395

Bishop ML, Fody EP, Schoeff LE 2010: Clinical Chemistry: Techniques, Principles, Correlations. Lippincott Williams \& Wilkins, Philadelphia, USA, 732 p.

Davis TA, Burrin DG, Fiorotto ML, Reeds PJ, Jahoor F 1998: Roles of insulin and amino acids in the regulation of protein synthesis in the neonate. J Nutr 128: $347-350$

Dwyer CM 2008: The welfare of the neonatal lamb. Small Rum Res 76: 31-41

Eckersall PD 2008: Proteins, proteomics, and the dysproteinemias. In: Kaneko JJ, Harvey JW, Bruss ML (Eds): Clinical Biochemistry of Domestic Animals. $6^{\text {th }}$ edn, Elsevier Academic Press, London, United Kingdom, pp. 117-155

Egli CP, Blum JW 1998: Clinical, haematological, metabolic and endocrine traits during the first three months of life of suckling Simentaler calves held in a cow-calf operation. J Vet Med 45: 99-118

Hammon HM, Schiessler G, Nussbaum A, Blum JW 2002: Feed intake patterns, growth performance and metabolic and endocrine traits in calves fed unlimited amounts of colostrums and milk by automate strating in the neonatal period. J Dairy Sci 85: 3352-3362

Janku L, Pavlata L, Misurova L, Filipek J, Pechova A, Dvorak R 2011: Levels of protein fractions in blood serum of periparturient goats. Acta Vet Brno 80: 185-190

Ježek J, Klopčič M, Klinkon M 2006: Influence of age on biochemical parameters in calves. Bull Vet Inst Pulawy 50: 211-214

Kaneko JJ, Harvey JW, Bruss ML 2008: Clinical Biochemistry of Domestic Animals. $6^{\text {th }}$ ed., Elsevier Academic Press, London, United Kingdom, 916 p.

Keren DF, Alexanian R, Goeken JA, Gorevic PD, Kyle RA, Tomar RH 1999: Guidelines for clinical and laboratory evaluation of patients with monoclonal gammopathies. Arch Pathol Lab Med 123: 106-107

Lomborg SR, Nielsen LR, Heegaard PMH, Jacobsen S 2008: Acute phase proteins in cattle after exposure to complex stress. Vet Res Commun 32: 575-582

Meyer DJ, Harvey JW 2004: Veterinary Laboratory Medicine: Interpretation and Diagnosis. $3^{\text {rd }}$ edn, Saunders, Philadelphia, $351 \mathrm{p}$.

Mohri M, Sharifi K, Eidi S 2007: Hematology and serum biochemistry of Holstein dairy calves: Age related changes and comparison with blood composition in adults. Res Vet Sci 83: 30-39

Piccione G, Costa A, Bertolucci C, Borruso M, Pennisi P, Caola G 2006: Acid-base balance modifications in the lamb and goat kids during the first week of life. Small Rum Res 63: 304-308

Piccione G, Casella S, Giannetto C, Vazzana I, Niutta PP, Giudice A 2009: Influence of age on profile of serum proteins in the calf. Acta Vet Beograd 59: 413-422

Piccione G, Scianó S, Messina V, Casella S, Zumbo A 2011: Changes in serum total proteins, protein fractions and albumin-globulin ratio during neonatal period in goat kids and their mothers after parturition. Ann Anim Sci 11: $251-260$

Piccione G, Arfuso F, Faggio C, Casella S, Zumbo A, Panzera M 2013: Serum protein profile in Comisana lambs during the first month of life. Arch Tierz 56: 1-21

Szewczuk M, Czerniawska-Piątkowska E, Palewski S 2011: The effect of colostral supplement on the serum protein fractions, health status and growth of calves. Arch Tierz 54: 115-126

Thomas JS 2000: Overview of plasma proteins and protein plectrophoresis. In: Feldman BF, Zinki JG, Jain NC (Eds): Schalm's Veterinary Haematology. $5^{\text {th }}$ edn, Lippincott Williams \& Wilkins, New York, USA, pp. 891-904 
Tiezt NW, Burtis CA, Ashwood ER 1994: Tietz Textbook of Clinical Chemistry. $2^{\text {nd }}$ edn, WB Saunders Company, Philadelphia, $2326 \mathrm{p}$.

Weaver DM, Tyler JW, VanMetre DC, Hostetler DE, Barrington GM 2000: Passive transfer of colostral immunoglobulins in calves. J Vet Inter Med 14: 569-577 